TITLE:

\title{
Menger Sponge-like Fractal Body Created with a Novel Template Method
}

\section{$\operatorname{AUTHOR}(S)$ :}

Mayama, Hiroyuki; Tsujii, Kaoru

\section{CITATION:}

Mayama, Hiroyuki ... [et al]. Menger Sponge-like Fractal Body Created with a Novel Template Method. 物性研究 2006, 87(1): 44-45

ISSUE DATE:

2006-10-20

URL:

http://hdl.handle.net/2433/110662

RIGHT: 


\title{
Menger Sponge-like Fractal Body Created with a Novel Template Method
}

\author{
†Nanotechnology Research Center, Research Institute for Electronic Science, \\ Hokkaido University and ${ }^{\ddagger}$ CREST (JST) Hiroyuki Mayama ${ }^{\dagger}{ }^{1}$, Kaoru Tsujii ${ }^{\dagger, \ddagger}$
}

細孔サイズ分布が $N(r) \propto r^{-D}$ で記述される多孔質体：フラクタル立体の作製とその幾何学的 性質について報告する。我々は、多孔質体の細孔に相当するテンプレート微粒子を作製・集積し、 微粒子間の隙間に入れた重合性の溶液を重合させることで最終的に多孔質物質（ポーラスシリカ） を得た。多孔質体は空隙率 $85 \%$ 、断面観察から $50 \mathrm{~nm}$ から $30 \mu \mathrm{m}$ の約 3 桁にわたるスケールにお いて断面フラクタル次元 $D_{\mathrm{cs}}=1.87$ であり、その幾何学的性質がフラクタル立体の数学的モデル Menger sponge（フラクタル次元 $D=\log 20 / \log 3=2.73 ） に$ 非常に近いこと $(D \sim 2.7)$ が分 かった。さらにフラクタル立体の $D$ の制御方法も確立した $(D=25 \sim 27)$ 。フラクタル立体に より空間次元の制御が可能となるため、様々な実験への応用が期待される。

\section{Summary}

Dimension is an essential control parameter as shown in charge density wave (CDW) [1] and quantum Hall effect.[2] Recently, it has been clarified that some systems with non-integer dimension (fractal) express new phenomena of the localization of electromagnetic wave[3] and super liquid-repellency[4], etc. Therefore, various new phenomena must be still lying behind fractal dimension. Here we show the first experimental results on the creation of a fractal body resembling Menger sponge[5] with a novel template method.

The essence was to adopt "flower-like particles" of a wax as template particles corresponding to pores. The particles were stacked, then the remained space between the stacked particles was filled by a tetramethyl orthosilicate (TMOS) solution, and it was solidified by a sol-gel synthesis. After that, sol-gel product were calcinated at $500^{\circ} \mathrm{C}$ for $2 \mathrm{~h}$. The porosity of the obtained porous silica was $85 \%$ ( 85 vol \%; air and 15 vol \%; $\mathrm{SiO}_{2}$ ).

From the SEM images of the cross sections of porous silica, cross-sectional fractal dimension $D_{\text {cs }}$ was determined. Fig. 1 show a $\log N(r)$ vs. $\log r$ plot obtained from a box-counting method, where $r$ is the box size and $N(r)$ is the number of boxes occupied by a fractal pattern. As a result, $D_{\mathrm{cs}}=187$ is maintained between two cutoffs, $50 \mathrm{~nm}$ and $30 \mu \mathrm{m}$, whereas $D_{\mathrm{cs}}=20$ below $50 \mathrm{~nm}$ and above $30 \mu \mathrm{m}$ within experimental error. Inset shows a plot of $d \log N(r) / d \log$

\footnotetext{
${ }^{1}$ E-mail: mayama@es.hokudai.ac.jp
} 
$r$ vs. $\log r$, which clearly shows that the slope is slightly gradual between tens nm and tens $\mu \mathrm{m}$, where $d \log N(r) / d \log r=-D_{\text {cs }}$.

Based on $D_{\mathrm{cs}}$, porosity and cutoffs, the fractal geometry of the porous silica can be discussed in comparison with mathematical models. From the viewpoint of $D_{\mathrm{cs}}$, we concluded that our sample $\left(D_{\mathrm{cs}}=187\right)$ was closer to Menger sponge because its $D_{\mathrm{cs}}=\log 8 / \log 3=1.89$. On the other hand, from the porosity and cutoffs, one can determine how fractal geometry or hierarchical pattern was developed. For example, volume fraction $f_{n}$ of Menger sponge at the $n$-th generation is described as $f_{n}=(20 / 27)^{n}$ and then $n$ is obtained from the relation of $r_{\text {size }}^{n}=r_{\text {low }} / r_{\text {upper }}$, where $r_{\text {size }}$ is the size reduction ratio $\left(r_{\text {size }}=1 / 3\right.$ for Menger sponge $), r_{\text {low }}$ and $r_{\text {upper }}$ are the lower and upper cutoffs, respectively. Based on the obtained porosity and cutoffs, we concluded that the fractal body was closer to the Menger sponge at the 7th generation and $D \sim 27$. Furthermore, porous silica with lower fractal dimension has been created $(D \sim 25)$. Fractal body would allow us to control system dimension.

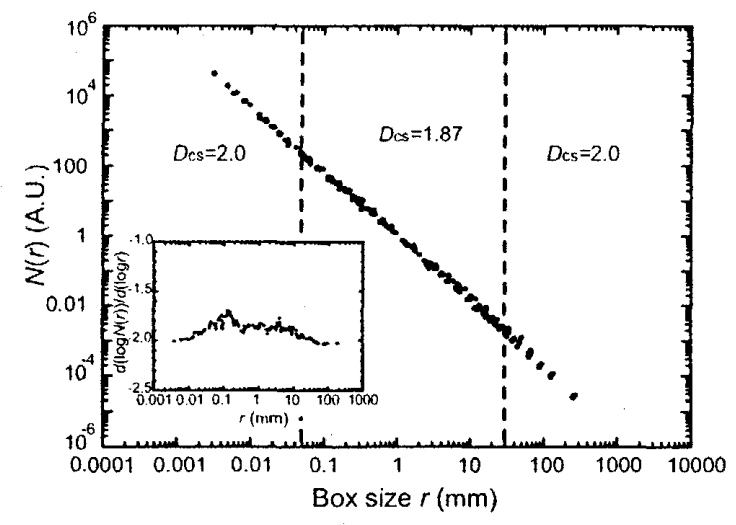

Figure 1: A plot of $\log N(r)$ vs. $\log r . D_{\mathrm{cs}}=187$ between $50 \mathrm{~nm}$ and $30 \mu \mathrm{m}$. Inset shows a plot of $d \log N(r) / d \log r$ vs. $\log r$.

\section{References}

[1] P. Monçeau, N. P. Ong and A. M. Portis, Phys. Rev. Lett. 37, 602 (1976).

[2] K. v. Klitzing, G. Dorda and M. Pepper, Phys. Rev. Lett. 45, 494 (1980).

[3] M. W. Takeda, S. Kirihara, Y. Miyamoto, K. Sakoda and K. Honda, Phys. Rev. Lett. 92, $093902(2004)$.

[4] S. Shibuichi, T. Onda, N. Satoh and K. Tsujii, J. Phys. Chem. 100, 19512 (1996).

[5] Benoit B. Mandelbrot, The Fractal Geometry of Nature, W. H. Freeman and Company, New York, 1977. 